J O U R A L O F

French and Francophone Philosophy
REV U D DE L A

philosophie française et de langue française

\title{
The Saint and the Cynic: Resentment and Jewishness in Améry, Sloterdijk, and Wyschogrod
}

Menachem Feuer

Journal of French and Francophone Philosophy - Revue de la philosophie française et de langue française, Vol XXIV, No 3 (2016) 95-116.

\author{
Vol XXIV, No 3 (2016) \\ ISSN 1936-6280 (print) \\ ISSN 2155-1162 (online) \\ DOI 10.5195/ jffp. 2016.789 \\ www.jffp.org
}

\section{(c)) EY-NC-ND}

This work is licensed under a Creative Commons Attribution-Noncommercial-No Derivative Works 3.0 United States License.

\section{UILIS D-Sorle}

This journal is operated by the University Library System of the University of Pittsburgh as part of its D-Scribe Digital Publishing Program, and is co-sponsored by the University of Pittsburgh Press 


\section{The Saint and the Cynic}

\section{Resentment and J ewishness in Améry, Sloterdijk, and Wyschogrod}

\section{Menachem Feuer}

York University

The constellation of pain, resentment, the body, and time - as they exist in the wake of the Enlightenment and in the dawn of a new barbarism - is found throughout the work of Jean Améry and Peter Sloterdijk. Both thinkers were especially influenced by Nietzsche's readings of resentment, his challenge to the Enlightenment, and his turn to the body as the basis of a new kind of thinking which starts with pain, dwells in irreversible time, and ends with the possibility of action and joy. While this new thinking is novel and appeals to all humankind, the most unexpected points of convergence between Améry and Sloterdijk can be found in their particular neoNietzschean articulations of Jewishness: using what Harold Bloom would call revision, they both propose a revision of Nietzsche's reading of Judaism as resentment. Améry associates Jewishness with "revolt" while Sloterdijk associates what he calls "kynicism" (as opposed to cynicism) with Jewishness. ${ }^{1}$ Intensely aware of the mortal blows that have been dealt to the Enlightenment, philosophy, and modernity as well as to the human body during the Holocaust, Améry and Sloterdijk both address - either directly or indirectly - the meaning of cynicism in relation to Jewishness, in particular, and the modern condition, in general.

How does cynicism offer modern man the greatest challenge and the most important opportunity? Améry's attitude toward cynicism is dual. In At the Mind's Limits: Contemplations by a Survivor at Auschwitz and its Realities, Améry suggests taking action, which is in solidarity with other Jews, in response to cynicism; but in his book, On Aging he does not. For the aging there is neither action nor solidarity; there is only pain, the body, and time. One can only reflect on one's body in pain as it moves toward death (in relation to which the subject marks time). While the former book challenges cynicism and resentment through action, the latter resigns itself to inaction 
and resentment. This is the route of the cynic who gives up on ever reversing time.

But one need not take this route. Edith Wyschogrod's reading of the body, pain, and time in terms of the Saint - which she contrasts to a Nietzschean reading of resentment - suggests a counterpoint to this cynical position. Wyschogrod contrasts what she calls the "affective" relation of the Saint-to-the-other to Nietzsche's "reactive" reading (which, ultimately, is cynical and kynical, depending on whether the reading of cynicism is made by Améry or Sloterdijk). Wyschogrod fears that what may be lost in the neoNietzschean reading of resentment is the vulnerability of the Saintly body which, in its relationship to the other, is exposed to the injury of the other. Although Améry focuses in on the vulnerability of the torture victim, Wyschogrod's work on the Saint suggests that, contra Améry, it is more important to start with the other's pain and resentment rather than my own. While her critique addresses Nietzsche and challenges Sloterdijk's claim that "kynicism" is the answer to cynicism, one wonders how it would address Améry's call (after Auschwitz) for "revolt." To address this question, we first need to turn to Nietzsche who Améry and Sloterdijk are deeply indebted so as to know what is at stake in the tension between the cynic and the saint.

\section{Nietzsche: Resentment, the Body, "Medicynicism," and J ewishness}

For Nietzsche, the appeal to weakness, guilt, and conscience, against which he directs most of his work, is rooted in Judaism. In The Genealogy of Morals, Nietzsche associates the "slave revolt of morals" and resentment with "the Jews." He likens it to a sickness that needs medication and suggests that not simply action but "medicynicism" is the cure. But before he posits the cure, Nietzsche gives a diagnosis of the illness which is, in part, based on a false understating of the body and its life. Nietzsche worries about the "health" threat posed to the "aristocratic warrior caste" by the "priestly aristocracy" which, though in a different form, remains, today: "Mankind itself is still ill with the effects of this priestly naiveté in medicine." 2

According to Nietzsche, the "grand politics" that he saw flourishing in Europe in the 19th century was based on a form of resentment and a desire for vengeance that is historically rooted in the "priestly aristocracy" that stretches back to the Second Temple era . The appeal to weakness made at during time and was (and, with all its carryoves, such as Christianity and Demoncracy, is), in other words, a smoke screen for the true, hidden motive: vengeance. Nietzsche doesn't accept this "grand politics" because he truly believes that the "warrior class" is more "healthy' and deserving of historical and political power that those who appeal to slave morality. He calls for a revaluation of these values, a return, if you will, to the aristocratic. 
The greatest obstacle to this "return" is "the mob" which, for Nietzsche, took over society "through the Jews." 3 In other words, democracy and its concern for the other would not be possible without the "Jewish revolt in morals": it started with the Jews, went through Christianity, and was transvalued into Enlightenment democracy and made into the law of the land (by way of the mobs). For Nietzsche the Jewish Slave Revolt in morals says "no" to life and "reacts" to it. In revolt against Master Morality, it "gives birth to new values." But these values, for Nietzsche, must be reversed if "life" is to be preserved:

The slave revolt in morality begins when ressentiment itself becomes creative and gives birth to values: the ressentiment of natures that are denied the true reaction, that of deeds, and compensate themselves with an imaginary revenge. While every noble morality develops from a triumphant affirmation of itself, slave morality from the outset says No to what is "outside," what is "different," what is "not itself"; and this No is its creative deed. 4

Action, for Nietzsche, is "real" not "imaginary revenge." The noble morality, in contrast, "acts and grows spontaneously," it "seeks its opposite" in order to "affirm itself." 5 The aristocratic warrior is healthy, independent, and happy while the "common man," who draws on and lives according to "slave morality," is "unhappy." For this reason, Nietzsche sees the pity for the "victim" and the common man to be a cloak for jealousy.

In broad brushstrokes, Nietzsche argues that the "symbol of this struggle" is "inscribed in letters legible across all human history": "Rome against Judea, Judea against Rome - there has hitherto been no greater event than this struggle, this question, this deadly contradiction. Rome felt the Jew to be something like anti-nature itself, its antipodal monstrosity as it were." 6 In effect, Nietzsche identifies with the Romans, not the Jews. Nietzsche finishes his reflections on resentment and the Jews by arguing that the best way to understand this tension is through a "physiological" as opposed to a "psychological" understanding of the difference between those who adhere to a "slave morality" and those who do not: "Indeed, every table of values, every "thou shalt" known to history or ethnology, requires first a physiological investigation and interpretation rather than a psychological one." 7

Is there any antidote to the sickness Nietzsche associates with Jews, slave morality, the common man, or the man of resentment? How does Nietzsche address "sickness" through language? Eric Blondel, in his book, Nietzsche: The Body and Culture, argues that Nietzsche saw his "shock phrases" as an activism devoted to reducing all things to physicality:

Nietzsche, on the one hand, proposes to apply physiological metaphors to culture - we might call him the 'culture doctor' - and, on the other hand he describes the stomach morally....Nietzsche 
multiplies certain shock phrases designed reduce thinks to the physiological' ${ }^{8}$

These "shock phrases" are aimed at the stomach, so to speak, in order to have an affect on the physiological. ${ }^{9}$ Blondel, citing Nietzsche's "Daybreak," suggests that Nietzsche turned to a satirical cynicism, in particular, as an antidote to Jewishness and slave morality. Nietzsche creates his own word to describe his role as a cynic and doctor:

Nietzsche presents himself as "medicynish" (medicynical), but he is much more zynish (cynical) than medizinish (medical) in his insistence on the body, even when he speaks of the physiological cause for the ideal...His "medicynicsm" is scarcely more than the reverse of the idealism that is a moral denigration of the psychosomatic totality of the body and spirit....The impact of numerous 'medicynical' phrases is less physiological than burlesque...The physiology we were expecting, therefore, does not go beyond the comical paradoxes of the cynical tradition, from Diogenes to Heine, via Montaigne or Swift, without ever attending the scatological heights gloriously scaled by Nietzsche's precursors. ${ }^{10}$

Blondel's reading of Nietzsche's cynicism suggests that despite Nietzsche's belief that his words and actions actually affects the body and health, that Nietzsche "confined himself to burlesque." For Nietzsche health is associated with the comic insult which eschews the past, the victim, etc. in the name of joyfully perpetuating itself over against the threat of resentment and pity. For Nietzsche the best way to deal with this hatred was to rhetorically attack a people (the Jewish people) and not just an idea. And this, for Nietzsche, must be done if one doesn't want to remain an unhappy cynic. He'd rather be a happy, cheeky "cynic doctor."

The metaphor is straightforward enough: for Nietzsche, cynicism, as medicine, saves life from sickness. In the face of life and death, the cynical doctor says a Roman yes to life's affirmation of itself and, in doing so, negates the "no" of Judea. That is his "creative deed." The bottom line is that the Nietzschean cynic has no interest in promises, truth, conscience, or memory so much as in power and in what Blondel calls cynical burlesque. For Nietzsche, who reduces everything to the physiological, in his inversion of idealism, the cynic is all body. The "Medicynic" looks to increase his body's physical strength and health by satirically challenging the sources of resentment. But he does so by way of revising the past. These types of readings of the body and resentment are revised by Sltoerdijk and Améry. But although they create something neo-Nietzschean some of their his cynical-bodily-egoity remains. 


\section{Neo-Nietzschean, Take One: Peter Sloterdijk on the Cynical and the Kynical}

In The Critique of Cynical Reason, Peter Sloterdijk revises Nietzsche's notion of resentment. He articulates what Nietzsche means by the medical cynic through the use of a different (yet original term): Kynicism. While he retains the notion of the kynic (as opposed to the cynic) as the antidote to idealism and the Enlightenment, Sloterdijk inverts Nietzsche's' attitude toward the past, pain, and Jews. The active "cheeky" agressivity of the cynic is, for Sloterdijk, the means to bring the body - which idealism left behind - back into the world. Sloterdijk's most novel move, which speaks to Jean Améry's project, is to claim that there is phenomenon called "Jewish kynicism" and that it is, after the Holocaust, definitive. There are many questions about this move, however. How does Diogenes - his model for cynicism - and his brand of "cheekiness" relate to what Sloterdijk calls Jewish kynicism? And how do we reconcile "cheekiness" with the sober response Jews have to history after the Holocaust? Jewishness has more akin to humility than to cheekiness, and Sloterdijk knows this.

What this tension discloses is a rift within his concept of cynicism. The problem, as we shall see, is Nietzsche. If one is to hold on to Sloterdijk's notion of "cheekiness" (to what Nietzsche would see as an "active" part of his brand of Master Morality) - the crux of Diogenes' kind of cynicism - how can one understand the response to pain that is not cheeky, which we see in Jean Améry's response to resentment? Does every response to powerlessness and trauma - if it is kynical - have to be cheeky if it is to be affective? And what does that say about the Jewish kynical body? Is it, because it is so cheeky, invulnerable? And does that make it Cynical rather than Saintly?

Sloterdijk defines cynicism, at the outset of the book, by way of Gottfried Benn who reads cynicism in terms of an "unhappy consciousness" that cannot, after being Enlightened, turn back to naïve consciousness; but in order to preserve itself, it must hide its unhappiness and act "as if" all is well when it knows it's not. ${ }^{11}$ To properly diagnose and describe cynicism as a problem, Sloterdijk looks into many different sources of cynicism their affects. But of those, the most prominent sources of cynicism are the radical changes in modern history and mass urbanization. They are, in large part, responsible for the spread of cynicism. Decay, death, and radical upheaval prompt it to grow.

In the preface to his book, Sloterdijk reflects on a topic that was quite familiar to Nietzsche: the death of philosophy, which of course, gives rise to the cynicism of the contemporary thinker:

For a century now philosophy has been lying on its deathbed, but it cannot die.... Its farewell has been torturously drawn out.... Faced with its demise, it would like now to be honest and reveals its 
secret. It confesses: the great themes - God, Universe, Theory, Praxis, Subject, Object, Body, Spirt, Meaning, Nothingness - all that is nothing. They are nouns for young people, for outsiders, clerics, sociologists. ${ }^{12}$

After making this confession, Sloterdijk takes the next step which is to define the new framework. Echoing Nietzsche, Sloterdijk suggests that it is power: "From the corpse of philosophy arose the modern sciences and theories of power in the nineteenth century in the form of political science, theory of class struggle, technocracy, vitalism, and in every form armed to the teeth.... Where Nietzsche....intended to be "dangerously" cold and without illusions, social democracy performed pragmatically - and exhibited a middle class joy in cultivation. Both spoke to power: Nietzsche by undermining bourgeois idealism with vitalism; the Social Democracies by seeking to gain access to the middle class." 13 Nietzsche's challenge to power, according to Sloterdijk, was that of the kynic:

Nietzsche's decisive self-characterization, often overlooked, is that of a "cynic" (Cyniker, with this he became, next to Marx, the most momentous thinker of the century. Nietzsche's "cynicism" offers a modified approach to "saying the truth": It is one of strategy and tactics, suspicion and disinhibition, pragmatics and instrumentalism - all this in the hands of a political ego that thinks first and foremost about itself, an ego that is inwardly and outwardly armored."14 (my emphasis)

Kynicism constantly challenges the "happy" Kantian and the "reasonable" mind, which is disembodied. Embodied, kynical thought, for Sloterdijk, is the future; to live, it must leave the cynical acceptance of a dying philosophy (instead of acting "as if" it is alive when it is dying):

Physiognomic thinking offers a chance to escape from the regime of disembodied and therefore evil minds. To announce a new critique of reason means to have a philosophical physiognomy in mind; that is not, as with Adorno, "aesthetic theory," but a theory of consciousness with flesh and blood (and teeth). ${ }^{15}$

Sloterdijk suggests that the starting point for this new kind of thinking is not simply the body; it is pain:

I believe that Critical Theory has found a provisional ego for critique and a "standpoint" that provides it with perspectives for a truly incisive critique - a standpoint that conventional epistemology does not consider - it is a priori pain. It is the basis of elevated, distanced critique that achieves grand overviews but a stance of extreme closeness - micrology. If things have become too close for comfort for us, a critique must arise that expresses this 
discomfort. It is not a matter of proper distance but of proper proximity. ${ }^{16}$

Now, critique is possible inasmuch as pain tells us what is 'true' and what is 'false'. However, there is a problem: "In the sensitive critique," which is "based on a reproachful attitude, composed of suffering, contempt, and rage against everything that has power," it "makes itself into a mirror of the evil in the world."17 And this, argues Sloterdijk, demonstrates a "paralyzing resentment." 18 He calls sensitive critique a "defensive thinking" in which the "masochistic element has outdone the creative element." 19 Sloterdijk brings back Nietzsche to argue that Kynicism can balance out these two elements. It can give Critical Theory a new life which isn't based, primarily, on pain and resentment against everything that has power. Instead of following Adorno's example, "where enlightenment appears as a 'melancholy science' (Adorno - trans), it unintentionally furthers melancholic stagnation," the "critique of cynical reason hopes to achieve more from a work that cheers us up." 20 The work that he refers to is the work of satire and cheekiness. He feels that Adorno has lost this Nietzschean Kynical sensibility. The question is whether his turn to a Nietzschean "gay science" totally displaces Adorno's "melancholy science."

Sloterdijk argues that history, in all its displacements, overturns paradigms and traditions and creates an "unhappy consciousness" that is germane to cynicism. Rather than just passively accept it, he suggests a more Nietzschean aggressive approach to keep the kynic from slipping into a reactionary or of even fascistic attitude. He agrees with the idea that time is irreversible, that we cannot go back, and that once one's world disappears we can no longer be naïve. On this note, he sees the task of ideological critique as incomplete. Simply showing that one's ideas are archaic, is ineffective. A more aggressive and joyful approach is needed if one is to combat power and cynicism. He turns to Diogenes- and not just Nietzsche for this approach.

In his chapter entitled "In Search of Lost Cheekiness," Sloterdijk takes Diogenes as the ultimate precursor for Nietzsche. Diogenes is a kynic, not a cynic:

With Diogenes, the resistance against the rigged game of "discourse" begins in European philosophy. Desperately funny, he resists the "lingusitification" of the cosmic universalism that called the philosopher to his occupation...He creates satirical resistance, an uncivil enlightenment. ${ }^{21}$

In Diogenes, "Greek kynicism discovers the animal body in the human and its gestures as arguments; it develops a pantomimic materialism. Diogenes refutes the language of the philosopher with that of the clown." 22 Diogenes, who Plato apparently calls the "mad Socrates," doesn't argue with his opponents. He mocks them and calls them name. In his "cheekiness," the 
"kynic farts, pisses, masturbate on the street, before the eyes of the Athenian market. He shows contempt for fame, ridicules the architecture, refuses respect, parodies the stories of gods and heroes." 23 Sloterdijjk insists that "only the theory of this cheekiness can open up access for the political history of combative reflections. This makes the history of philosophy possible as dialectical social history: It is the history of the embodiment and splitting of consciousness." 24

Sloterdijk, in the very same section that he describes Diogenes as a model, suggests that while Diogenes is the precursor for the European revolt against philosophy, it is "the Jewish David" who is "prototype of the cheeky." $25 \mathrm{He}$ "teases Goliath, 'Come here, so I can hit you better'. He shows that the head has not only ears to hear and obey but also a brow with which to menacingly defy the stronger: rebellion, affront, effrontery." 26 In doing this, Sloterdijk suggests that we understand Jewishness in terms of "cheekiness," thereby making Diogenes and "the Jewish David" into kin.

Near the end of Sloterdijk's book, "Jewish cynicism" comes up. But this time Sloterdijk returns to themes of "melancholy science" to explain it. He frames his explanation in terms of what he calls "black empiricism":

Black empiricism.... with a frequently justified suspicion... asks only which principles, which right, is power based on, but also which rights the powerful infringe in their exercise of power.... What drives this....is a political trauma: to have been exposed without projection to the "legitimate" but brutal, painful, oppressive force and violence of others - the power of parents, disciplinary force, power (military, police, executive) force and violence, sexual violence and coercion. The trauma gives birth to the critical attitude. It's a priori: Never again be struck; never again swallow offenses without resisting; never again, if possible, allow a hegemonic power to do violence against us. The critical stance is allied at its origin with Jewish kynicism against the arrogance of the more powerful. ${ }^{27}$

The repeated "never again" that Sloterdijk employs (echoing Eli Weisel) suggests a kind of kynicism, however, that has more in common with melancholic science than gay science. There is no cheekiness here. However, Sloterdijk seems to suggest that the drive to get a confession from the perpetrators is:

This critique tends toward wanting to wring from the ruling powerful confessions of their violence and immorality. It comes down to...exposure of the wolves in sheep's clothing by the "humbled and insulted." 28

Strangely enough, Sloterdijk doesn't return to this notion of Jewish kynicism; but in the final chapters he alternates between history (the 
Weimar and the raise of the Nazi party in Germany) and satire. It leaves the reader to wonder about how kynical efforts failed to stop Germany from sliding into cynicism, Nazism, and the Holocaust (which goes unmentioned at the end of the book).

Sloterdijk's gloss on Jewish Kynicism, the alluded to failure of cynicism, and the omission of the Holocaust are telling and provide us with the proper framework to address Jean Améry's work and his neoNietzschean revisions. What Sloterdijk doesn't make clear is that the "cheekiness" of Jewish Kynicism is much different from what we find in the satirical tradition that emerged out of Diogenes. The truth of the matter is that while a German Jewish thinker like Heine was cheeky in his satirical depictions of Germans and Jews, he didn't look to "wring from the powerful confessions of their violence and immorality." That came later, after the Holocaust. This cheekiness is of a different sort. And one wonders whether it actually shows that Adorno's "melancholy science" is more helpful in understanding "Jewish kynicism." Sloterdijk suggests that it is not because it is too masochistic and unhappy. But how is demanding an apology "gay"? Isn't it rooted in pain? Or is the demand itself, because it is unheard of, cheeky and "gay science"? Let's turn to Jean Améry for an answer. Like Sloterdijk's appeal to cynicism, it draws on Nietzsche as a precursor but it doesn't take everything he says.

\section{Neo-Nietzschean, Take Two: Améry's Revisionary Readings of Resentment, Revolt, and J ewishness}

Like Theodor Adorno, Jean Améry wonders about how and whether, after the constant exposure to pain, torture, and death in the concentration camps, modernity can turn to Enlightenment ideals. History and time, for Améry, are irreversible. One cannot go back to any original naiveté or innocence that existed before the Holocaust. What remains in its wake is a kind of cynicism and resentment; they run throughout Améry's books - such as At the Mind's Limits, On Aging, and Radical Humanism. Like many cynical thinkers, Améry realizes that, after Auschwitz, idealism and Enlightenment ideals have failed and cannot be fully recovered. After what he calls "the first blow" (to the body), Améry realizes that these same ideals failed to stop the unthinkable from happening. He realizes that he was naïve to think that they could. In At the Mind's Limits, Améry comes to the realization and conclusion that, after Auschwitz, "if the intellect was not centered around a religious or political belief, it was of no help, or little help. It abandoned us. It constantly vanished from sight whenever those questions were involved that were once 'ultimate ones.'" $29 \mathrm{He}$, at the time, could turn to neither religion nor politics; he was not raised as a religious Jew and wasn't politically oriented. However, what he did have at his disposal was a cogent and deep 
understanding of philosophy and literature. He saw himself and life itself through their prisms. But they failed:

The reality of the camp triumphed effortlessly over death and over the entire complex of the so-called ultimate questions. Here, too, the mind came up against its limits...The axes of its traditional frames of references then shattered. Beauty: that was an illusion. Knowledge: that turned out to be a game with ideas. Death violated itself in all its inscriptibility. ${ }^{30}$

In the wake of such overwhelming failure, Améry concluded, like Sloterdijk and Adorno, that instead of Enlightenment philosophy and modern literature being the fundamental starting points for understanding, critique, and action, physical pain, cynicism, and resentment - which emerge out of the mind's failure to transcend endless suffering and death and torture and are based in the social - are where new thought departs and returns. He states this emphatically, in the last paragraph of At the Mind's Limits:

In my incessant effort to explore the basic condition of being a victim, in conflict with the necessity of being a Jew and the impossibility of being one, I believe to have recognized that the most extreme expectations and demands directed at us are of a physical and social nature. That such knowledge has made me unfit for profound and lofty speculation, I know. It is my hope that it has better equipped me to recognize reality. ${ }^{31}$

While Peter Sloterdijk notes that "every critique is a pioneering work on the pain of the times," 32 Améry suggests that in response to the cynicism and resentment produced by history, a proper phenomenological description of historical existence - free from the naiveté that situates the mind above time and pain - must be articulated. Once this is done, Améry tells us that a decision must be made about whether and how one should act in response to such historical pain. This choice - because it is based on historical experience - is not between one idea and another. Action, as Améry and Sloterdijk understand it, is physically and socially conditioned and, if it is to be affective, it must be embodied. Moreover, action is in response to the irreversibility of time and physical pain.

Améry, like Adorno and Sloterdijk, is interested in pain as the a priori origin of critique. But it is also, as Nietzsche might say, the source of resentment (which Améry takes quite seriously and associates with the experience of utter hopelessness and victimhood). Améry aptly calls it - in particular reference to his own experience of torture and to discourse in general - the "first blow": "The first blow brings home to the prisoner that he is helpless, and thus it already contains in the bud everything that is to come." 33 This experience deprives him of his dignity and the "expectation of help" what he calls "the fundamental experience of human beings." 34 Améry expands on his particular experience to arrive at a generalization 
about pain. After the first blow, everything changes and the tragedy of time's irreversibly is brought to bear on the subject: "But with the first blow from a policeman's fist, against which there can be no defense and which no helping hand will ward off, a part of our life ends and it can never be retrieved." 35

Améry tells us that violence destroys idealism. This is a far cry from Sloterdijk's read on Kynicism and his appeal to "gay science." In Améry's description of torture and its transformation of man into the flesh, we see man as totally helpless and powerless:

Only in torture does the transformation of the person into the flesh become complete. Frail in the face of violence, yelling out in pain, awaiting no help, capable of no resistance, the tortured person is only a body, and nothing else besides that. ${ }^{36}$

The tortured man has no agency. He can't be "cheeky." Pain, for Améry, is the a priori, just as the body is the a priori: "Pain...is the most extreme intensification imaginable to our bodily being." 37

Building on the notion that pain marks irreversibility, Améry likens it to being exiled, perpetually, from home. After being tortured, one cannot find home. One cannot trust the world or be in it; moreover, torture is so great that one, apparently, doesn't even have the desire to have revenge (in the Nietzschean sense). In the wake of victimization, resentment remains, but without any hope of revenge. ${ }^{38}$ One would think that no action in the wake of torture seems possible for the torture victim. Their victimization is so extreme that they can't have any desire for revenge; moreover, they seem to be totally wordless and will remains so because they don't feel at home in the world and never will. This language is extreme.

In a chapter devoted to resentment, Améry takes on a different tone. It is personal and it actually ponders the possibility of action (despite the fact that reversibility is impossible; and he does suggest that he has lost all desire as a result of torture): "I speak as a victim and examine my resentments." 39 When reflecting on them, Améry takes note of how resentment is a historical and existential phenomenon. ${ }^{40}$ But even though they are a part of his history and, over time, will disappear (after all, as they say, time heals all wounds), he tells the reader something novel; namely, that he is making a decision about how to deal with them. In other words, he is not simply, as Nietzsche would say, reacting but acting: "I preserve my resentments. And since I neither can nor want to get rid of them, I must live with them and am obligated to clarify them for those against whom they are directed." 41 Améry's claim that he has an "obligation" to clarify them to those "against whom they are directed" suggests that he is looking for something from them. 
His choice to explain his resentment is also coupled with his refusal to walk into the future and forget about the past: "The man of resentment cannot join in the unisonous peace chorus all around him, which cheerfully proposes: not backward let us look forward, to a better, common future." 42 In holding his resentments, he is proposing a different reading of Nietzsche that gives the "man of resentment" some agency. Moreover, by going against the grain, he is "cheeky" in a way that Diogenes is not. Unlike Nietzsche's man of resentment, Améry believes that others in history will make the perpetrators confess and admit to their guilt. Améry lacks the "desire, talent, and conviction" 43 but he believes that "through actualization, or more strongly stated, by actually settling the unresolved conflict in the field of historical practice" 44 that he can, at least through someone else, experience a kind of reversibility of time:

I want at least the vile satisfaction of knowing that my enemy is behind bars. Thereupon I should fancy that the contradiction of my madly twisted time-sense (that is, his sense of irreversibility and perpetual powerlessness) were resolved. ${ }^{45}$

Améry calls this a "revolt against reality" a "moral solidarity" with others who are also men of resentment. He hopes that his resentment can "perform a historical function." 46 But near the end of the book, he admits that he bears his grudge "for reasons of personal salvation." 47 Here resentment - contrary to Nietzsche - is active because it may also be "for the good of the German people." 48

Améry suggests, like Sloterdijk, a new kind of Jewishness which, in some ways, is kynical because it draws on resentment to strike back:

Our resentments - emotional source of every genuine morality, which was always the morality of the losers - have little or no chance at all to make the evil work of the overwhelmers bitter for them. ${ }^{49}$

But this is the irony. Nietzsche's extreme reactions to Slave Morality show that it actually did make it bitter for those in power for centuries. In effect, Améry is taking on an active form of Slave Morality because he is directly making the oppressor bitter, and, as Sloterdijk would say, confess their guilt.

In the final section of the book, Améry embraces his Jewish particularity but he does so through this kind of revolt against the biological passing of time and forgetfulness. Unlike Nietzsche, he doesn't embrace "active forgetfulness": "I became a person not by subjectively appealing to my abstract humanity, but by discovering myself within the given social reality as a revolting Jew and by realizing myself as one." $50 \mathrm{He}$ is, in at least one sense posited by Sloterdijk, a kynical Jew. But he gives this term much more meaning than Sloterdijk. 
While Améry's kynicism and his nuanced readings of resentment, Jewishness, time, and revolt in At the Mind's Limits (1966) seem to state his final words on resentment, his book On Aging, which he wrote only two years later (1968), suggests conclusions about resentment, history, and action which are at odds with his 1968 text. Although Améry doesn't address the Holocaust or torture in that book, he does address the irreversibility of time and the possibly of revolt. This book, when read against At the Mind's Limits, suggests that not all people can act or affect the world. At a certain point, the aging are less concerned with the world and more concerned with the body's pain. They live with resentment and alienation but can't do anything about it. Revolt is out of the question. From this book, we learn that only a being who is young can affect history and revolt against it. The aging cannot.

Playing on Marcel Proust's Remembrance of Things Past, Améry suggests that narrator of his book cannot naively believe in the lies he or she may posit about the power of memory. The time of the narrator - the time posited by fiction - is not real. Time can only be redeemed in literature. In real life it cannot: "It is time, lived time, or if you will, subjective time, which is our most urgent problem." 51 Speaking as an author and a person, Améry tells the reader that "time is our arch enemy and our most intimate friend...our pain and our hope." 52 Améry contrasts the literary narrator (who he calls " $\mathrm{A}$ ") to a physicist (who he calls " $\mathrm{B}$ "). ${ }^{53}$ Who is right? Is time by way of memory - reversible or is it - by virtue of necessity - irreversible? Based on the experience of aging, Améry argues that the physicist is right and the writer is wrong: "The time of which we become aware in aging is not only something we cannot grasp; it is also filled with absurdity, a bitter mockery of every intellectual precision we have aspired to." 54 Only the young can expect things in the future. ${ }^{55}$ The aging can only expect more pain and death. ${ }^{56}$

When one ages one "doesn't exactly believe anymore in the world and what's in store for him." 57 As the world fades, time goes inside of our bodies. ${ }^{5}$ In contrast, for the young "time...movers in space." 59 The world is open to the young. The old experience the negation of space: "For what once was world, was space, but not it is only time." 60

Only the aging, who all at once know how to count the autumns and the winters with horrifying exactness, since they still measure seasons against those that have passed and gone into them, understand the passage of time as an irreversibility - too horrible to complain about, since so much has slipped by and already run past. 61

Améry's judgment is harsh: Irreversibility cannot be reversed through memory or literature. ${ }^{62}$ For the aging, as opposed to the narrator in his novel, the "feeling (of lost time) is constantly present within them - and not 
only because of the diminishing power of their bodies or the increasing sufferings these bodies cause them - that they carry time insides themselves and therefore do not even need to realize the past in their memory." 63

While Améry talks about the "first blow" by torture or violence in At the Mind's Limits as ever-present, he knows it can be reversed or revolted against by way of history and confession of guilt; here he suggests that aging and the receding world cannot be revolted against. The "body's blemishes" take one out of the world. 64 There is no space for the aging, only time. One degenerates and becomes smaller. ${ }^{65}$ One becomes a thing. ${ }^{66}$ For Améry, this happens when the world you lived in no longer exists. World and time are the ultimate judges.

In all of this, Améry, never speaks of solidarity or revolt. He comes to the conclusion that one can and must resign oneself to irreversibility at a certain point of one's life. One is alone and powerless. Here, his reading of aging is wholly cynical and not kynical. There is nothing cheeky in this book save for his renunciation of Proust and the possibility of literature. This cynicism contradicts what we find in At the Mind's Limits.

\section{Wyschogrod: Against Nietzsche, Against Resentment}

Contrasting Améry's different readings of irreversibility, the body, and resentment - which are informed in some way by Nietzsche's and echo Sloterdijk's - to Edith Wyschogrod's reading of the Saint and her body, we find that there is a fundamental contrast between the cynic and the saint. This difference has a lot to do with how the Saint's body differs from the Nietzschean, kynical body. Moreover, it has to do with a different take on altruism, resentment, and irreversibility.

Wyschogrod's reading of the Saint draws on Emmanuel Levinas so as to present a challenge to Nietzsche's take on resentment and the body. Levinas's take on sensibility is the basis for her reading of the Saint's vulnerability. "Sensation is affective rather than reactive; moreover, it is recoverable. 67

According to Wyschogrod, citing Levinas, there is a "temporal difference, but it is time in which nothing is lost." Because the sense impression involves a recovery of time, it is still temporalized through the time scheme of presence." 68 And it is this "affective side of sensation" which "can be experienced as pure vulnerability: what is other than the self can affect the self through pain or wounding." 69 Although this "dimension of corporeal existence is common to all," Wyschogrod argues that Saints, because they pose "no obstacle to experiencing this vulnerability, permit it to acquire primacy in their lives."70 The cynic, on the contrary, would not permit this to happen. Like the victim of torture, but unlike Améry's kynical 
Jewish subject in The Mind at the Limits, "the saint is without defenses, unsheltered, exposed to insult and outrage." 71

Wyschogrod is cognizant of what this suggests and notes that "such denuding of the self's form, such stripping it of empowerment, would appear to leave the self open to the violence and aggression of others." 72 And "this by no means precludes that defenselessness will not be met by aggression. To the contrary: violence is a frequent response to vulnerability and constitutes the first of saintly life."73 The Saint's vulnerability is a response to the "other's destitution," but "saints are not masochistic to derive satisfaction in suffering." 74 It is, rather, the "need and lack of the Other, not pleasure in the experience of pain, that constitutes the appeal of the saint and authorizes or provides the warranty for saintly activity in the everyday world."75 By putting it this way, Wyschogrod suggests that the Saint has no personal motive or satisfaction in being vulnerable. She is forthe-other.

The time of being for the other is irreversible: "When it is bound up with the Other, time imprints itself on the pain and suffering the enucleated self accepts in the interest of the Other. Time that impresses itself in this way does not come to fruition in pain so that pain is the culmination of...time.... time throbs without ceasing." 76 This time is "irrecoverable" and is not the culmination of the kind of work that is "self-empowering". It is "renunciation of power" that, in aging while waiting for the other, there is a passing of time that is not recoverable. Its irreversibility is for the other, not the self. Unlike Améry, this is not tragic for the aging self because it is waiting for the other.

After making this case for Saintly time and vulnerability, Wyschogrod takes up "Nietzsche's objections" to altruism and in doing so she addresses resentment, the body, and his notion of irreversibly that go hand-in-hand with cynicism and, as I would argue, cynicism: "Altruism has historically been rooted in affect, in compassion or pity for the other." 77 Wyschogrod cites Aristotle to support this view that the pity is expressed in the face of the other's misfortune: "on this view, if I pity the other I must see the other as blameless so that the other's suffering cannot be attributed to a selfgenerated error or moral failing." 78 In contrast to this, Nietzsche cynically suspects pity: "on his view, pity is the emotion that is felt when the desire for revenge is suppressed. ${ }^{79}$ As Wyschogrod underscores, Nietzsche favors vengeance over resentment:

If someone injures me, I may strike back directly or I may delay my response. When I strike back, I spontaneously discharge my vengeful feeling so that it no longer acts upon my psychological life, but when weakness or fear prevents this direct discharge of affect, my frustrated rage turns into resentment. Pity is the fruit of this emotion. 80 
Wyschogrod cites Nietzsche's Genealogy of Morals so as to point out how diametrically opposed the Saint is to Nietzsche's subject: "'Impotence which cannot retaliate,' Nietzsche declares, 'is turned into kindness, pusillanimity and humility'" (Genealogy of Morals, I, 14). As I noted above, Nietzsche thinks this "impotence" is unhealthy. For him, this "instinctual degeneration" 81 goes hand in hand with "the excessive development of consciousness and the hypertrophy of reason." 82 And "as a result of both inner and institutional repression, a new human type is created, the man of ressentiment." 83

In response to Nietzsche's reading, Wyschogrod brings up two "counterarguments." One by Max Scheler, the other by Gilles Deleuze. However, as she notes, while the former gives a direct criticism of resentment, the latter does so indirectly in his analysis of "reactive forces." She finds both counterarguments to be weak. ${ }^{84}$ Wyschogrod suggests that, by taking a closer look at "Nietzsche's notion of life" we can "elicit some presuppositions bound up with Nietzsche's vitalism that will clear the way for a fresh interpretation of Saintly compassion and pity." 85 Wyschogrod cites the urgency of this appeal by noting how Sloterdijk carries Nietzsche's notions of resentment and pity into his own work. ${ }^{86}$ Although she doesn't explain why this is the case, she takes note of how Nietzsche's reading of the body enters into postmodern discourse.

Wyschogrod, in her effort to "elicit some presuppositions bound up with Nietzsche's vitalism," points out that, for Nietzsche "the joy of becoming is a corporeal joy" and the "will to power" is "nothing less than the body's self-expression as force." 87 Based on this, she argues that his reading of the body is to narrowly conceived:

It can be argued against Nietzsche that he has given the body too narrow an interpretation. His account cordons off a feature of the corporeality that is intrinsic to it: the body's vulnerably. To be as embodied existence, as flesh, is to be vulnerable. This is not a property of diseased bodies but of bodies generally. While Nietzsche acknowledges and even celebrates death, he segregates the phenomenon of vulnerability - sensitivity to temperature, fatigue, exhaustion, sleep, the like - from death itself." 88

Building on this point, Wyschogrod points out that Nietzsche's body is perpetually vigilant and wakeful. Nietzsche's take on the body's wakefulness "refuses to acknowledged the body's slackness exhibited by phenomena such as fatigue and sleep." 89 And because there is such a perpetual awareness of vitality, there is no room for memory since all affect is immediate; there is no temporal delay that would inform memory. 90 The only memory he cherishes, as I pointed out above, is the "memory of the will" which, as Wyschogrod points out "refuses to become slack." 91

Wyschogrod acknowledges that while her reading of the body, in contrast to Nietzsche's, poses a strong objection, it still doesn't get at the 
"origin of resentment." Wyschogrod comes up with three questions that address this problem: "Is there something in the character of existence itself that Nietzsche sees as bringing the "spirit of revenge" into being? If so, can the spirit of revenge by overcome? And, if Nietzsche thinks it can, how does his view affect the view of saintliness I have proposed together with the notion of time integral to it?" 92 The main enemy for Nietzsche and the origin of resentment is time's passing: the "it was". Wyschogrod focuses on the vitalist response to this rather than the literary/mythological response. As Wyschogrod points out, the "irreversibility of time entails the will's inability to will backward....under the inexorable pressure of time, the will sees itself as responsible for its helplessness before time's directionality and superimposes a burden of guilt upon a prior condition of existence." 93

Nietzsche was acutely aware of and wrote frequently of time's irreversibility and "develops a phenomenology of time as physiological, cosmological, and cultural aging as well as of historical irreversibility." He "superimposed on this construal of time...a notion of the power of human agency to trick time as it were while still retaining the truth of time's irreversibility and the innocence of becoming." 94 And this is the main point for Wyschogrod, Nietzsche's conception of the body and the origin of resentment both entail a reading of the body and time in a cynical manner.

Wyschogrod juxtaposes this to the Saint's take on the body and irreversibility. As I noted above, it is the other's pain and the time lost in attending to it that is irreversible. She calls this "dark diachronicty." 95 Drawing on trauma (and reminiscent of what Améry calls the "first blow" and the experience of aging), Wyschogrod points out how unique moments in life are irrecoverable but color our experiences. ${ }^{96}$ Although this kind or unique time cannot be regained and is irreversible, she asks if "there is any way of annulling the past or negating the future that takes time's dark diachrnonicity into account, that respects both the newness of experience and the irrecoverabillty of time?" The answer, for Wyschogrod, is yes: "Repentance and apology, pardon, and forgiveness are phenomenon that erase the past while maintaining time's irreversibility." 97 In other words, the key difference between the cynic and the saint has to do with how we read irreversibility and the body in relation to the social dimension:

In repentance the process is reversed not because the will wills backward in Nietzsche's sense but because the offence created by acts against the Other is undone so that the offense no longer exits. Unlike repentance, apology and forgiveness are social acts in which the undoing of the past offense requires reciprocity: the Other must be complicit in granting pardon. ${ }^{98}$ 


\section{Conclusion}

Wyschogrod's formulation suggests a framework that can be used in relation to understanding Améry's desire to see the "Germans behind bars" and admitting to their wrongdoing. While, as I have noted above, Améry in On Aging, is acutely aware of time's irreversibility and thinks that, for the aging, nothing can be done to battle against time and social alienation, he does allow for some kind of reversibility in At the Mind's Limits. He acknowledges that he will not be the same, physiologically, after the first blow. But this social admission does make him feel better. To be sure, Améry's desire for "personal salvation" is motivated by holding close to and acting on his resentments and taking historical action. It is based on a "revolt" against time's irreversibility. But that doesn't make him a Saint. He is, as Sloterdijk would say, a Jewish kynic. He sees the root of his desire to react in his neo-Nietzschean reading of the body, pain, and time. The most important thing, it seems, is to remain strong. And this is found in his affirmation of Zionism. As he notes in his essay "Being a Jew" Jewishness changed after the Holocaust:

They beat us when it pleased them... They may have been destined to be slaves of the master race; but we were signed over to death. It reached the point where we Jews allowed ourselves to be beaten without resistance. Only once did I strike back, in the mistaken belief that in this way I could retain my human dignity. Then I recognized that it made no sense. The Jew was the sacrificial animal.... To be sure I had not acquired Judaism in the sense of historical tradition and a positive existential foundation of life. The only thing that binds me positively to the majority of Jews in the world is a solidarity with the State of Israel....For me, solidary with Israel means keeping faith with my dead comrades. 99

While Améry doesn't pardon or forgive the Nazis for what they did, he does allow for social redress. But that seems to be less important for him than making sure that Jews are no longer deemed a "sacrificial animal." This desire is more rooted in a Nietzschean sense of the body and power. It tends more to the cynic than the saint. The State of Israel puts the Jewish people into the realm of history and power from which they were, over history, excluded. It marks a new beginning and a different kind of Jewishness that is more kynical.

However, we can't forget that Améry wrote On Aging two years after he wrote At the Mind's Limits. Although he sees himself in solidarity with other Jews and Israel and although he believed that social admission of wrongs against Jews was important and put Jews into a better historical position than they had in the past (after all, Jews never asked any nation for admission of guilt once it went into exile), he ultimately thought of himself as an individual alienated from the world and subject to aging, pain, 
vulnerability, and time's irreversibility. His body, as he notes in On Aging, was his main concern as he aged, not the world. This articulates a kind of cynicism because it is an admission that, in contrast to the saint, my time will not be lost in waiting for the other or attending to the other. In On Aging, Améry is telling his reader that his time and his resentment have to do with his pain, his death, and his wordlessness, and nothing can reverse that. On a final note, I suggest that we read this book against the other books and essays because, in doing so, we can see that although there is a tension in Améry's work between the cynic and the saint, in the end the vigilant Nietzschean body fails. Améry insists, there, that irreversible time cannot be redeemed either through memory, willing, sarcasm, or history. But if I start with the other's pain and resentments rather than my own, that need not be the case because then the time I lose is lost for someone else. That's another story which, perhaps, may never be seen on the stage of history yet, nonetheless, happens every day when, despite our age, this or that saint attends to the suffering.

${ }^{1}$ The difference between kynicism and cynicism will be explained in the essay. Also, take note, that whenever Sloterdijk mentions cynicism in relation to Nietzsche, he associates it with kynicism. But others, such as Harold Bloom, seem to be suggesting a different variety of cynicism.

${ }^{2}$ Nietzsche, Friedrich. The Genealogy of Morals, trans. Walter Kaufmann, Vintage: New York, 1989, p. 32 (From here on GM)

3 Ibid. p. 36

4 ibid. p. 36-37.

5 Ibid. p. 37.

${ }^{6}$ Ibid. p. 34.

${ }^{7}$ Ibid. p. 55.

${ }^{8}$ Eric Blondel. Nietzsche: The Body and Culture: Philosophy as Philological Genealogy, trans. Sean Hand (Stanford: Stanford UP, 1991), 228. (From here on NBC)

${ }^{9}$ Ibid.

$10 \mathrm{lbid}$.

11 Ibid. p. 6.

${ }^{12}$ CCR, p. xxvi

13 Ibid., p. xxvii

14 Ibid. p. xxix

${ }^{15}$ Ibid. p. xxxi

16 Ibid. p. xxxiii 


\author{
17 Ibid. xxxiv \\ 18 Ibid. \\ 19 Ibid. " p. xxxv \\ 20 Ibid. p. xxxvii \\ 21 lbid. p. 102 \\ 22 Ibid. p. 103. \\ 23 Ibid. p. 103-104. \\ 24 Ibid. p. 102. \\ 25 Ibid. p. 103. \\ 26 Ibid. \\ 27 Ibid. p. 339. \\ 28 Ibid. \\ ${ }^{29}$ ATM, p. 15. \\ 30 lbid. p. 19. \\ 31 Ibid. p. 101. \\ ${ }^{32}$ CRC, p. xxxvi. \\ 33 Ibid. p. 27. \\ 34 Ibid. p. 29. \\ 35 Ibid. \\ 36 Ibid. p. 33. \\ 37 Ibid. \\ 38 Ibid. p. , 40. \\ 39 Ibid. p. 63. \\ 40 Ibid. p. 64. \\ 41 Ibid. p. 67. \\ 42 Ibid. p. 69. \\ 43 Ibid. \\ 44 Ibid. \\ 45 Ibid. \\ 46 Ibid. p. 77. \\ 47 lbid. p. 80. \\ 48 Ibid.
}


$49 \mathrm{lbid}$.

50 lbid. p. 91.

${ }^{51}$ J ean Améry, On Aging, trans. J ohn Barlow (Bloomington: Indiana UP, 1994), 5. (From here on OA)

52 Ibid.

53 Michel Houllebecq does something nearly identical to this in his book Elementary Particles.

54 OA, p. 8.

55 lbid. p. 9

${ }^{56} \mathrm{Ibid}$.

57 Ibid. p. 14.

${ }^{58} \mathrm{Ibid}$.

${ }^{59}$ Ibid. p. 15.

$60 \mathrm{Ibid}$.

61 Ibid. p. 18.

62 Ibid. p. 22.

63 Ibid. p. 23.

64 Ibid. p. 25.

65 Ibid. pp. 39; 42; 43; 104

66 Ibid. p. 110.

${ }^{67}$ Edith Wyschogrod, Saints and Postmodernism: Revisioning Moral Philosophy (Chicago: University of Chicago Press, 1990), 97. (From here on SP)

68Ibid. p. 98.

69 lbid.

$70 \mathrm{lbid}$.

71 Ibid.

$72 \mathrm{Ibid}$.

${ }^{73} \mathrm{Ibid}$.

${ }^{74}$ Ibid. p. 99.

$75 \mathrm{Ibid}$.

76 Ibid.

77 Ibid. p. 100.

$78 \mathrm{lbid}$.

79 Ibid. 


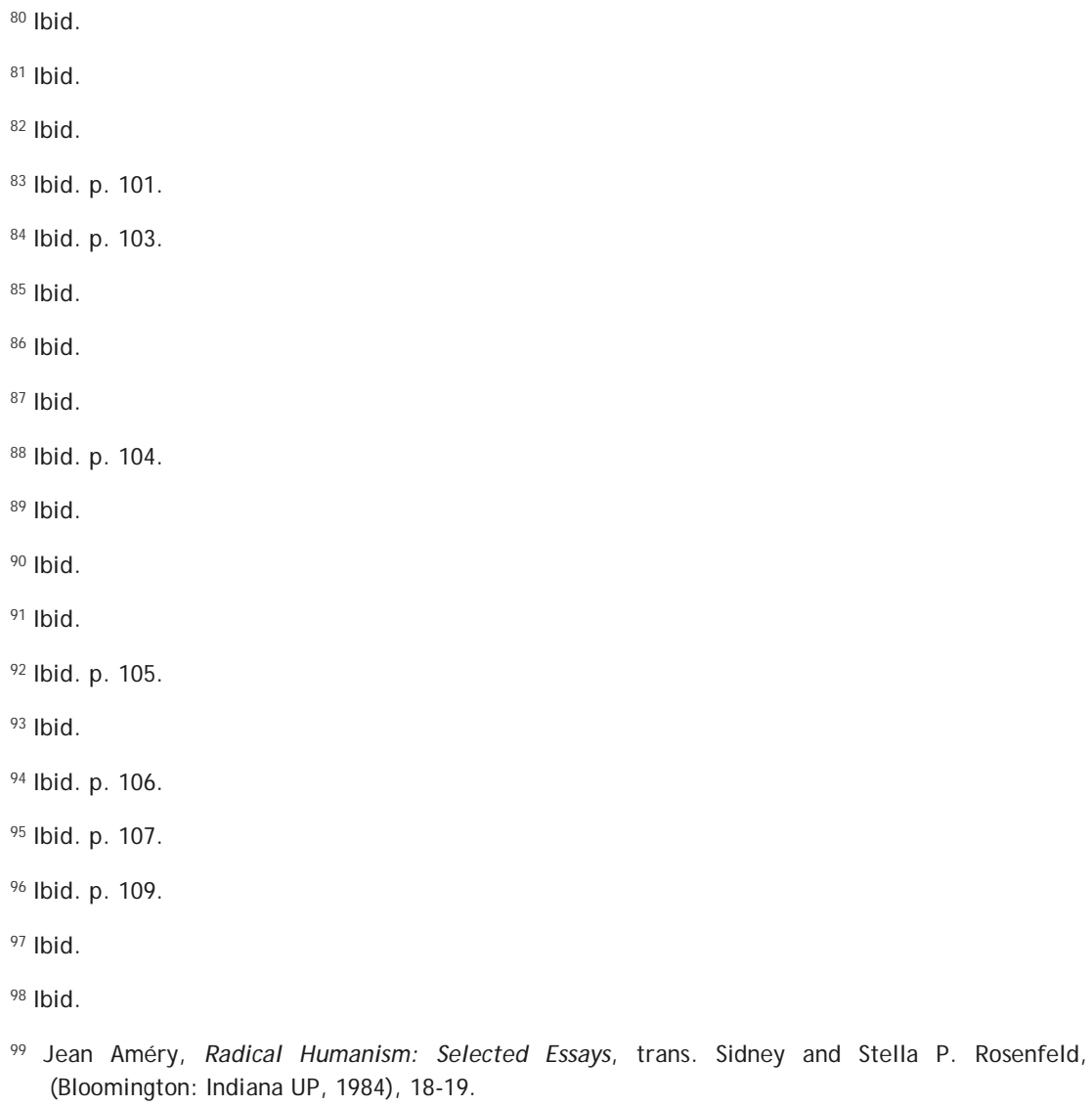

